مقاله يزوهشى

مجله دانشگاه علوم يزشكى رفسنجان

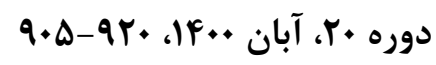

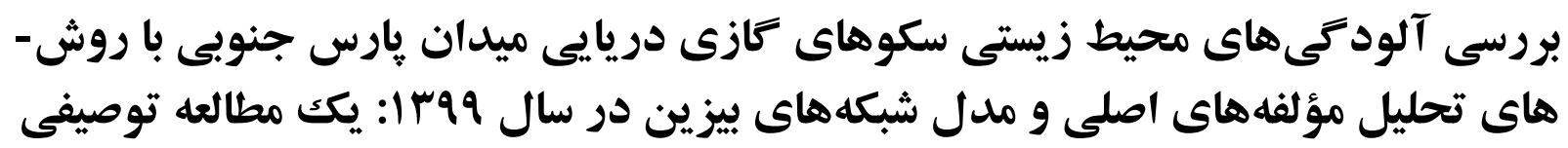

رضا محمدز اده'، مهناز ميرزا ابر اهيم طهرانى '، سيد على جوزى'، ركسانا مو كويىع

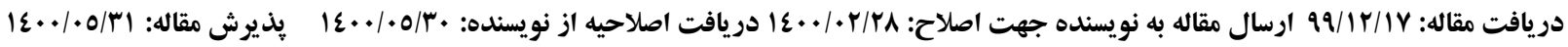

زمينه و هدف: در سطح جهانى افزايش تقاضاى انرزى، انسان را به دنبال استخراج نفت و كاز حتى در اعماق درياها سوق داده

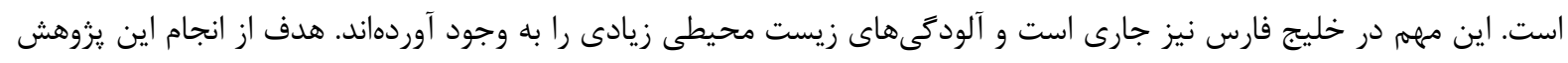

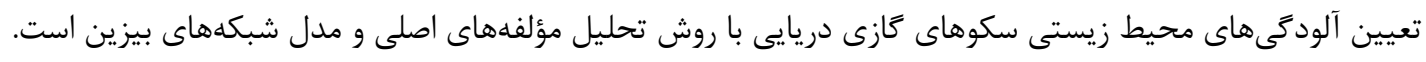
مواد و روشها: اين يزوهش توصيفى در سال و9جا بر روى سكوهاى كازى دريايى ميدان يارس جنوبى انجام شد. دادهاى مورد

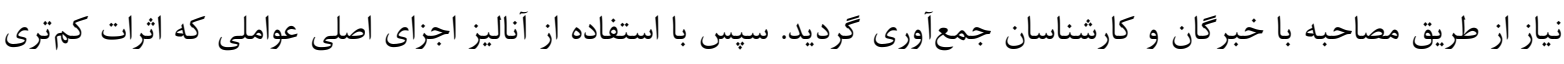
دارند، حذف و ساير عوامل در شبكههاى بيزين مورد بررسى قرار كرفت.

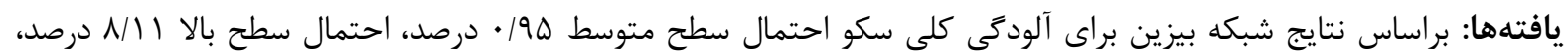

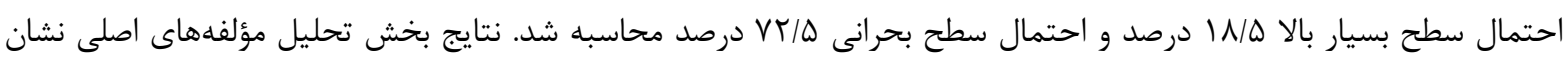
داد بيشترين واريانس مربوط به مؤلفه اصلى اول و مقدار آن تقريباً • F درصد و همهنين بيشترين مقدار ويزه نيز مربوط به اين مؤلفه با مقدار 9 • 1/9 مىباشد.

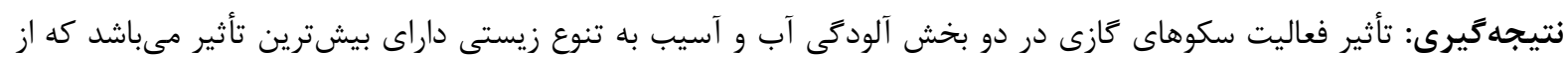

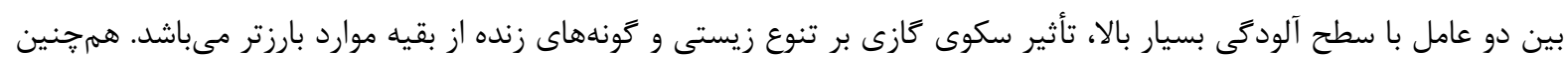

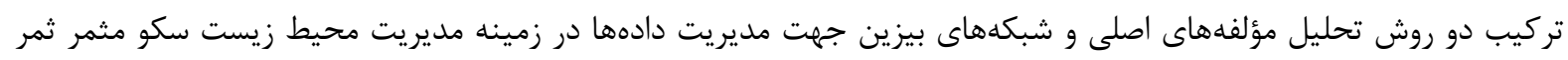
مىباشد. وازههاى كليدى: آلودَى، سكوى كازى، مؤلفه اصلى، شبكه بيزين

ا- دانشجوى دكترى تخصصى، گروه محيط زيست، دانشكده علوم و فنون دريايى، دانشكاه آزاد اسلامى، واحد تهران شمال، ايران

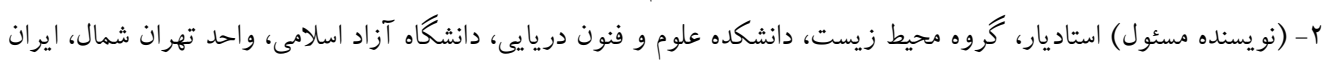

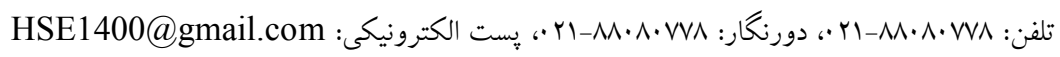

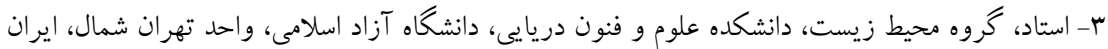

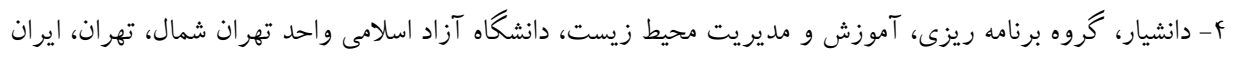


9.9 بررسى آلودگىهاى محيط زيستى سكوهاى گازى دريايى ميدان بارس جنوبى ...

ماتريس همبستخى متغيرهاى اصلى به دست مىآيند. به

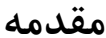

طور كلى كاربرد عمده روش تحليل اجزاى اساسى عبارت از

كاهش تعداد متغيرها و يافتن ساختار ارتباطى بين متغيرها

كه در حقيقت همان دسته بندى متغيرها است، مىباشد

شبكهاى بيزين سيستمى بر اساس نظريه احتمالات است

كه توسط توماس بيز (Thomas Bayes) ابداع شده است [ع]

كه در واقع يك نوع خاص از مدلهاى گرافيكى هستند كه

نماينده ساختار وابستگى بين جندين متغير اثركذار بر هم مى تى

باشند. به طور كلى شبكههاى بيزين براى حالاتى مفيدند كه

وضعيت فعلى سيستم به وضعيت قبلى آن بستخى دارد.

بنابراين مىتوان از شبكههاى احتمالاتى براى تصميمگيرى و

استدلال در شرايط عدم قطعيت استفاده كرد. با استفاده از

اين شبكهها مىتوان احتمالات يسين متغيرهاى خروجى را با

استفاده از مقادير مشاهداتى متغيرهاى ورودى محاسبه نمود

[V] إز اين روش مشهور مىتوان جهت مدلسازى در حوزه

هايى مانند مديريت محيط زيست كه داراى عدم قطعيت-

$$
\text { هاى فراوانى است، بهرهخيرى نمود [^-1]. }
$$

Elbisy به بررسى مديريت محيط زيستى يك سكوى

كازى به همراه خطوطه لوله انتقال آن در درياى مديترانه

يرداخت و جنبdهاى محيط زيستى و آلودگىهاى ناشى از

آن را ارزيابى كرد و همجنين اشاره نمود كه استخراج نفت و

كاز و عمليات توليد بسته به سطح فرآيند، ذات و حساسيت

محيط اطراف و تكنولوزى توليد، پتانسيلهاى زيادى براى اثر كذارى بر محيط دارند [•[1]. Ellis و همكاران به بررسى جهارجوبهاى مديريت محيط زيستى استخراج فراساحلى براى نيوزلند يرداختند. در اين يزوهش، اطلاعات كليدى از

كاهش روز افزون منابع انرزى در جهان لزوم توجه به

مديريت زيست محيطى مصرف انرزى را افزايش مىدهد [1]. افزايش تقاضاى انرزى انسان را به دنبال حفارى و استخراج نفت و كاز حتى در اعماق درياها و اقيانوسها سوق داده است. در طول ينجاه سال كذشته، بهرهبردارى از منابع تجديدنايذير براى پاسخَّيى به تقاضاى جهانى براى انرزى، به شدت افزايش يافته و به موازات اين افزايش استخراج، آلودگىهاى محيط زيستى ناشى از فعاليتهاى سكوهاى دريايى نيز بالا رفته است [؟]. مواد نفتى از منابع مختلفى وارد آب مى گردد و بيشترين منابع آلودگى مربوط به خاهها، دكلها و سكوهاى فراساحلى مىباشد [ب]. امروزه اين عوامل آلوده كننده به يك نترانى اساسى تبديل شدهاند و قوانين محكمى از طريق كنترل محيط زيستى اعمال مى عوامل بايد اولويتبندى شوند، به طورى كه اولويتبندى بر اساس دادهها منجر به تشكيل يك مدل براى مديريت آلودگىهاى محيط زيستى سكوهاى كازى شود كه در

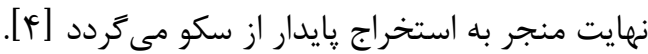
براى تعيين عواملى كه بيشترين تأثير در ايجاد آلودگى توسط سكوهاى نفتى را دارند از روش تحليل مؤلفه اصلى استفاده مىشود. در اين (Principal Component Analysis) روش متغيرهاى موجود در يك فضاى جند حالته همبسته به يك مجموعه از مؤلفههاى غيرهمبسته خلاصه مىشوند كه هر يك از آنها تركيب خطى از متغيرهاى اصلى مىباشند. مؤلفههاى غير همبسته به دست آمده، مؤلفههاى اساسى ناميده مىشوند كه از بردارهاى ويزه ماتريس كوواريانس با 
كرفته است و بخش ايرانى آن از اصلىترين منابع انرزى كشور به شمار مىرود. ذخاير كاز اين ميدان عظيم حدود 1 درصد كل ذخاير كاز جهان و بخش ايرانى آن نزديك به نيمى از ذخاير كَاز كشور را شامل مى كردد. مساحت اين ميدان ·9V كيلومتر مربع است كه سهم متعلق به ايران rV. . ميدان در حدود f| || تريليون متر مكعب كاز به همراه 11 ميليارد بشكه ميعانات كازى تخمين زده مىشود [ـا I] به منظور گردآورى دادهها از طريق برسشنامه و اخذ نظر Health and ) HSE از كارشناسان و خبركان با تخصص (Safety Executive محيط زيست، عواملى كه دراى اهميت بيشتر بودند، مشخص و شناسايى شدند. براى تهيه دادها از نظر كارشناس نظر سنجى شد كه r نفر از كارشناسان به علت درج دادههاى يرت، حذف گرديدند و از نتايج • ا نفر خبره

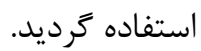

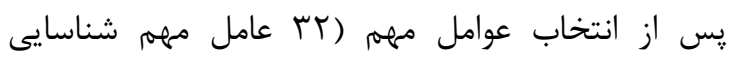
گرديد)، مقدار (ابعاد و دامنه)، شدت، احتمال وقوع (جداول ا تا r) براى اين عوامل به صورت يرسشنامه نظرسنجى كرديد. - م
يزوهشهاى بين المللى بررسى شدند كه مىتوانند سيستم مديريت محيط زيست را يجىريزى كنند [11]. Beyer و همكاران در بررسى اثرات محيط زيستى تخليه آبهاى ساحلى توليد شده ناشى از فعاليت استخراج نفت و گَاز ساحلى توسط سكوهاى كازى بيان كردند كه اين فعاليتها سبب آلودگى آب مىشوند. اين آبهاى تخليه شده عمدتاً شامل تركيبات نفت خام براكنده، هيدروكربنهاى آروماتيك קند حلقهاى، آلكيلها و غيره مىباشد [ I I]]. از اينرو، هدف از انجام اين يزوهش شناسايى عوامل ايجاد كننده آلودگى در سكوهاى گازى دريايى ميدان يارس جنوبى با استفاده از تحليل مؤلفههاى اصلى و شبكه بيزين مىباشد. به اين منظور با استفاده از شبكه بيزين كه ابزارى قوى و كارآمد در مديريت مسائل محيط زيستى و مسائل داراى عدم قطعيت است، عواملى كه بيشترين يا كمترين اثر بر محيط را دارند، شناسايى گرديدند.

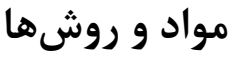

يروهش حاضر از نوع توصيفى مىباشد كه در سال 99 1 بر روى سكوهاى گازى دريايى ميدان گارس جنوبى انجام شد. ميدان كازى يارس جنوبى (كنبد شمالى در بخش قطرى) بزرگترين منبع گازى جهان است كه بر روى خط مرزى مشترك ايران و قطر در آبهاى خليج فارس قرار 
^• • بررسى آلودگىهاى محيط زيستى سكوهاى گازى دريايى ميدان يارس جنوبى ...

جدول | - طيف شدت اثوخطرات عوامل آلوده كننده محيط زيست [ع|]

\begin{tabular}{|c|c|c|}
\hline تعريف/مصاديق شدت اثر & درجه أاثير & اثر \\
\hline هيجَّونه خطر و تأثير زيست محيطى منفى رخ نمى دهد. & 1 & 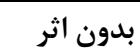 \\
\hline خطر براى كاركنان و محيط زيست محسوس نيست. & r & ناجيز \\
\hline خطر براى كار كنان و محيط زيست دردسر ايجاد مى كند. & r & جزئى \\
\hline خطرات اتفاق افتاده باعث ناراحتى كاركنان و عناصر محيط زيست مىشود/تأثير محسوس. & p & كم \\
\hline تأثير خطر در محيط زيست سبب مراجعه ضابطين بهداشتى و توقف كوتاه مدت كار مىشود. & $\Delta$ & متوسط \\
\hline خطر باعث بروز خسارت و آلودىى قابل توجه اما جبراننايذير به محيط زيست مىشود. & \& & زياد \\
\hline خطر اتفاق افتاده در محيط زيست به صورتى است كه نياز به پاكسازى و تصفيه و غيره دارد. & $\checkmark$ & خيلى زياد \\
\hline خطر اتفاق افتاده در محيط زيست، باعث از بين رفتن بخشى از عناصر محيط زيست يا & $\wedge$ & جدى \\
\hline 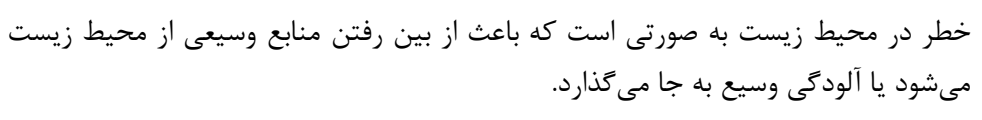 & 9 & 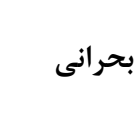 \\
\hline خطر در محيط زيست به صورتى است كه منابع طبيعى، محيط زيست جانورى، كياهى و & 1. & فاجعه بار \\
\hline
\end{tabular}

جلول + - طيف احتمال وقوع خطرات محيط زيستى مقياس الكاريتمى [10]

\begin{tabular}{|c|c|c|c|c|c|c|c|c|c|c|}
\hline 1 & Q/• & $\Lambda / \cdot$ & $V /$. & $8 /$. & $\Delta /$. & $F / \%$ & $r / \bullet$ & $r / \bullet$ & $1 /$. & وقوع احتمال \\
\hline دائمى & حداكثر روزانه & حرز يك اتفر هر & هفتخى يكى & ماهيانه r حداكر & ساليانه & سالفانه 9 & سالفانه r حاكر & ساليانه يكى & مورد در سال & تفسير \\
\hline
\end{tabular}

بعد از تحليل مؤلفههاى اساسى، سه مؤلفه اصلى به دست جدول ب - ابعاد و دامنه (مقدار) خطر عوامل آلوده كننده محيط آمد و بردارهاى ويزه براى تشكيل هر مؤلفه ارائه كرديد. در ادامه روند كار، مؤلفهاى كه داراى بيشترين واريانس و بردار ويزه بود، به عنوان مؤلفه اصلى اول انتخاب كرديد. براى تعيين عواملى كه بيشترين تأثير را داشتنند از مؤلفه اصلى اول (Principal Component) استفاده كرديد و عواملى كه داراى مقدار عددى مؤلفه اصلى اول كمتر از ها هار بودند، حذف و از ساير عوامل در تحليل بيزين استفاده

\begin{tabular}{|c|c|}
\hline ابعاد & تفسير \\
\hline$r-1$ & خيلى كم \\
\hline$r-r$ & كم \\
\hline $9-\Delta$ & متوسط \\
\hline$\Lambda-\gamma$ & زياد \\
\hline $1 \cdot-9$ & خيلى زياد \\
\hline
\end{tabular}

تحليل مؤلفههاى اساسى از طريق كد نويسى در نرمافزار نسخه / MATLAB بر اساس اطلاعات ارائه شده صورت كرديد [19] گرفت. در اين تحليل مقدار، شدت و احتمال وقوع آلودگى Netica مدلسازى شبكه بيزين با استفاده از نرمافزار نسخه ه/ ه انجام شد و آلودگى سكوهاى گَازى فراساحلى به متغيرهاى مسئله بودند. با توجه به اينكه از دادهاى سه متغير(مقدار، شدت و احتمال وقوع آلودگى) استفاده شد، لذا 
جداگانه تشكيل و جهار سطح متوسط، بالا، بسيار بالا و بحرانى بررسى گرديدند و در ادامه روند كار ييشنهادات مديريتى ارائه كرديد [IV]

\section{نتايج}

كارشناسان مختلف، عوامل متعدد ايجاد كننده آلودگى توسط سكوهاى گازى را پيشنههاد دادند كه از بين اين عوامل، r T عامل كه بين كارشناسان مشترك بوده، براى بررسى انتخاب شدند كه به شرح جدول ذيل مىباشد:
سه دسته آلودگى هوا، آلودگى آب و آسيب به تنوع زيستى محيط آبى تقسيمبندى شدند. در شبكه بيزين ورودىهاى كرههاى مربوط به آلودگى هوا، آلودگى آب و آسيب به تنوع زيستى تعيين گَرديدند. براى هر يك از اين گرهها سه حالت متوسط، بالا و بسيار بالا در نظر گرفته شده است. سيس احتمالات شرطى اين گرهها بر اساس نظرات كارشناسان و خبر كان تهيه و مدلسازى شبكه بيزين انجام شد. براى هر يك از آلودگىهاى آب، هوا و همرجنين آسيب به تنوع زيستى شبكه بيزين و جداول احتمالات شرطى به صورت

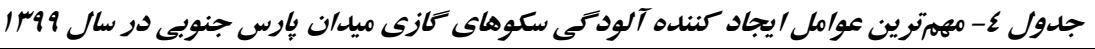

\begin{tabular}{|c|c|c|c|c|c|c|c|}
\hline بيامد & جنبه محيط زيستى & عامل & رديف & بيامد & جنبه محيط زيستى & 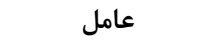 & رديف \\
\hline صوتى آلودگى & ايجاد نويز & سركو آلودى فعاليت & IV & آلودگى & 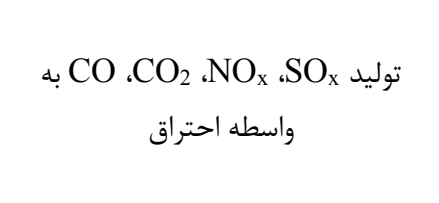 & 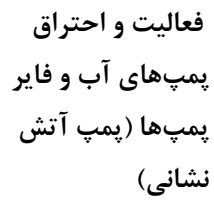 & 1 \\
\hline صوتى & ايجاد نويز & 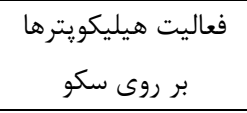 & 11 & آلودگى & آلودگى ذرات معلق به علت بدسوزى احتمالى در زنراتور & $\begin{array}{r}\text { احتراق زنراتورهاى } \\
\text { مولد برق }\end{array}$ & r \\
\hline 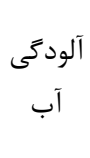 & آلودگ نشت مايعات و بستر دريا & سرخاهى توسط سرى فنشار & 19 & هوآى آلودى & آلودَى ذرات معلق به علت بدسوزى احتمالى در زنراتور & سلرينَ يا مشعل & $r$ \\
\hline 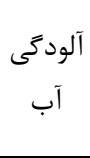 & آلودى ميع دريايى & 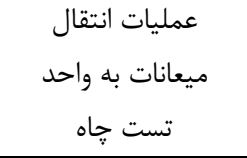 & $r \cdot$ & آلودگى & انتشار به & سوزئ با فشار كم & f \\
\hline 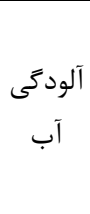 & نشت كاندنسيت & 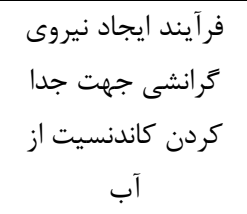 & YI & آلودىى & آلودگى نورى در هنحام برداشت از منبع & در منطق كردن جراغ نور & $\Delta$ \\
\hline 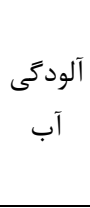 & دفآبعاى آب همراه و & خرابى تجهيز و دفع & rt & زتيير در & نشت كاز و ميعانات به دليل خوردذى & خرورد & 4 \\
\hline 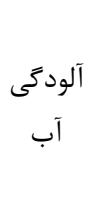 & 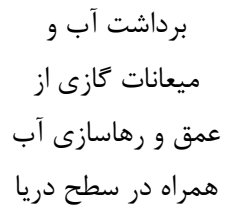 & 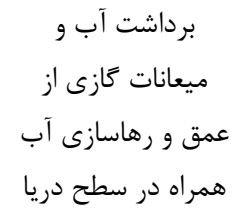 & $r$ & صوتى آلودىى & ايجاد نويز در محيطهاى آبى & فازى فاليت توربينهاى & $\checkmark$ \\
\hline
\end{tabular}


• ا بررسى آلودگى هاى محيط زيستى سكوهاى گازى دريايى ميدان يارس جنوبى ...

\begin{tabular}{|c|c|c|c|c|c|c|c|}
\hline بيامد & جنبه محيط زيستى & 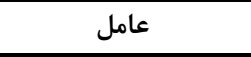 & رديف & 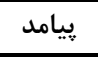 & جنبه محيط زيستى & 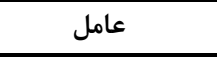 & رديف \\
\hline زتيير در & هنعًام فعاليت اسيد دمراه در & جرداشت ميدواش لولههاى & $T^{K}$ & 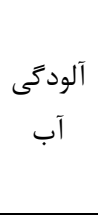 & نشت كندانسيت در آب دريا & 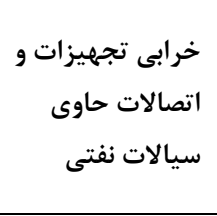 & $\wedge$ \\
\hline زتنيير درع & سولفوريك و اسيد & جربت درداشت ميعانات & $r \Delta$ & 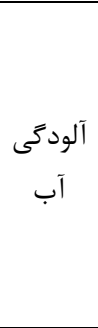 & 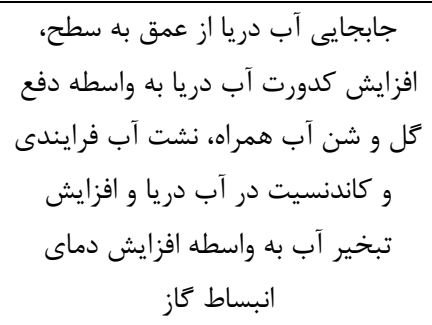 & فعاليت جاهرها و و & 9 \\
\hline زتيير در & 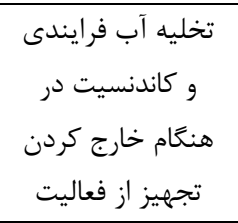 & تعمير تجهيزات & re & 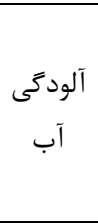 & ففع تركيبات آنتى كروزن به هنكام & بيعَرانى & 1. \\
\hline تغيير در & 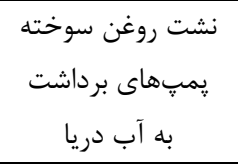 & 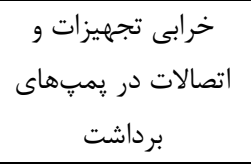 & $T V$ & 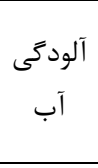 & دفع تركيبات اكساينده در آب دريا & الكتروليز آب & 11 \\
\hline تنيير در & نشت آنتى كروزن & خرابى تجهيزات و آترات حاوى آنتى & $r \Lambda$ & 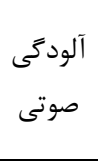 & افزايش نويز و ارتعاش در محيطهاى & فرداليت و بهره- & $\pi$ \\
\hline زتيير در & تنظيدروليك در هنتام & 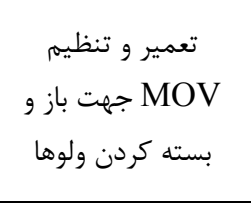 & rq & 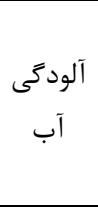 & 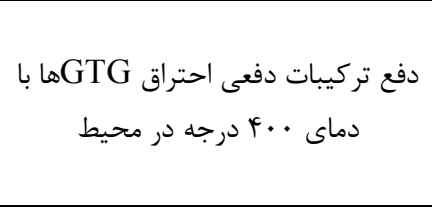 & 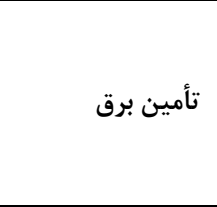 & r \\
\hline 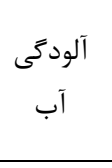 & 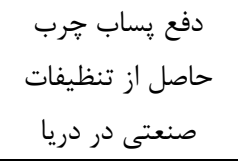 & شابزارآلات و قطعات كارى & $r$. & 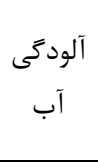 & نشت تينر و حلالهاى رنحت در آب & 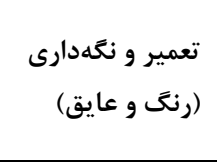 & If \\
\hline 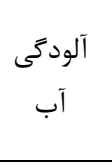 & كشتى هاب شر دريا & 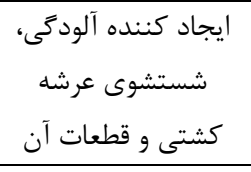 & rl & 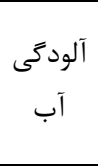 & نشت پِاب حاصل از تنظيفات صنعتى & 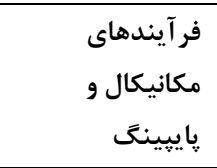 & is \\
\hline 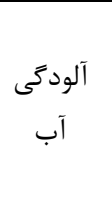 & توليد يساب حاصل & اقامت و تهيه و طبخ & Tr & صوتى آلودىى & ايجاد نويز به هنكام نزديك شدن & 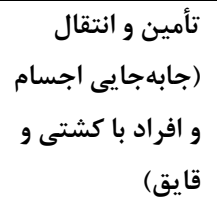 & 18 \\
\hline
\end{tabular}

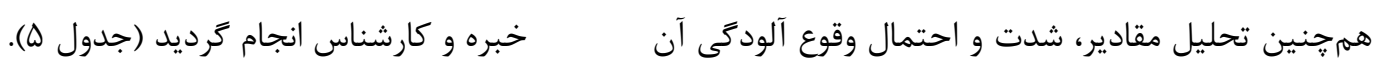
ها براى rr عامل مشخص شده، بر اساس ميانگين نظرات 


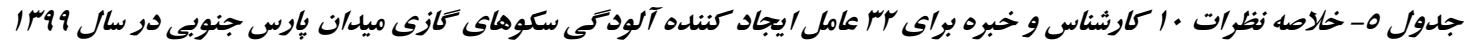

\begin{tabular}{|c|c|c|c|c|c|c|c|}
\hline مقدار & شدت & احتمال & عامل آلودتى & مقدار & شدت & احتمال & عامل آلودَىى \\
\hline$r$ & $V / \Delta$ &.$/ 9$ & IV & .119 & $N / r$ & .119 & 1 \\
\hline$r / r$ & $V / F$ & $\cdot 119$ & 11 & $\cdot 119$ & $\Delta / V$ & $\cdot 119$ & $r$ \\
\hline$r / V$ & $\Delta / \Delta$ & $\cdot|r|$ & 19 & $\cdot 1 / 9$ & $9 / 1$ & .109 & $r$ \\
\hline$r / f$ & $\Delta / r$ & . /Tr & $r \cdot$ & $N / V$ & $V / r$ & . /AV & p \\
\hline$r / \varphi$ & $V / 1$ & $\cdot / r$ & rI & $\Delta$ & $\Delta / V$ & $\cdot / 19$ & $\Delta$ \\
\hline$\Delta / \Lambda$ & $\Delta / 9$ & . Mt & tr & $N / \Lambda$ & $\Delta / T$ & .109 & 4 \\
\hline$F / \Delta$ & $\Delta / r$ &.$/ 9$ & r & 9 & $\Delta / 1$ & $\cdot / 9$ & v \\
\hline$r / \varphi$ & $\Delta / \Delta$ & . $/ \Delta T$ & TF & $\Delta$ & $\Delta / 1$ & $\cdot 1 / 9$ & $\wedge$ \\
\hline$r / 4$ & $9 / 4$ &.$/ 9$ & rQ & $1 / 9$ & $V / 9$ &.$/ 9$ & 9 \\
\hline $9 / 1$ & $F / V$ & $\cdot / 9$ & rq & $\Delta / \Delta$ & $r / 9$ & $\cdot 199$ & 1. \\
\hline$\Delta / r$ & $F / V$ & $\cdot / 4$ & Tr & $r / \varphi$ & $g / 4$ & $\cdot / 19$ & 11 \\
\hline$V / r$ & $F / \mathcal{F}$ & $\cdot / \Delta F$ & rA & r & $V / \omega$ & $\cdot / 19$ & ir \\
\hline$q / r$ & $F / \mathcal{G}$ & $\cdot / 9$ & rq & 9 & $\Delta / 9$ & $\cdot / r \Lambda$ & ir \\
\hline$r / \omega$ & $f / f$ & $\cdot / r$ & $r$. & $\Delta / 9$ & $F / r$ & $\cdot / r \Lambda$ & If \\
\hline$V / T$ & $\Delta / 9$ & $\cdot \mid 94$ & ri & $r / l$ & $\Delta / r$ & $\cdot / r$ & 10 \\
\hline$r / T$ & 919 & $\cdot / V^{4}$ & rT & $T / 9$ & $V / F$ & $\cdot 119$ & 19 \\
\hline
\end{tabular}

\begin{tabular}{|c|c|c|c|}
\hline $\begin{array}{r}\text { مؤلفه سوم } \\
\text { (PC3) }\end{array}$ & $\begin{array}{r}\text { مؤلفه دوم } \\
\text { (PC2) }\end{array}$ & $\begin{array}{c}\text { مؤلفه اول } \\
\text { (PC1) }\end{array}$ & \\
\hline$\cdot|V \cdot r|$ & $\cdot / \cdot 101$ &.$/ 2119$ & احتمال (Probability) \\
\hline$-\cdot|9| \cdot \Delta$ & $-\cdot 10 \cdot 1 r$ & سז| & شدت (Intensity) \\
\hline.$/ r 49 \Delta$ & - MAQS & . ITFt & مقدا, (Amount) \\
\hline
\end{tabular}

براى تعيين عواملى كه بيشترين تأثير را دارند از مؤلفه اصلى اول (PC1) استفاده مىشود. براى تشكيل مؤلفه اول مقادير مشخص شده احتمال در /119/ • مقدار مشخص شده شدت در سباع|• و مقدار مشخص شده مقدار آلودگى در ץ اس/ • ضرب و نتايج آنها با يكديگر جمع گرديد (شكل
با توجه به اينكه از دادهاى سه متغير استفاده شده است، لذا بعد از تحليل مؤلفههاى اساسى سه مؤلفه اصلى بهدست مى آيند. مقادير ويزه (Eigenvalues) سه مؤلفه اساسى در جدول \& ارائه شدهاند. جدول V بردارهاى ويزه براى تشكيل هر مؤلفه را نشان مىدهد. مقادير واريانس مربوط به

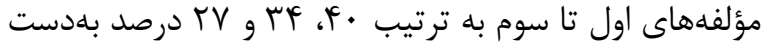
آمد. در واقع در تشكيل مؤلفه اول، به ترتيب احتمال رخ داد، شدت و مقدار بيشتر تأثير گذار هستند.

\begin{tabular}{|c|c|c|c|}
\hline & لفه اصلى & $\frac{\text { بروئً }}{\lambda_{2}}$ & و \\
\hline مقادير ويزه & $1 / \cdot 19 \cdot 9$ & $1 / \cdot \Delta r$ & $\cdot \mid \lambda \cdot r \Lambda$ \\
\hline
\end{tabular}




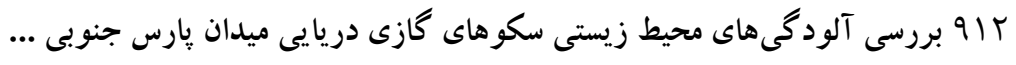

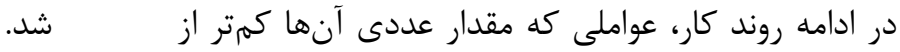

ه بودند، حذف و از ساير عوامل در تحليل بيزين استفاده

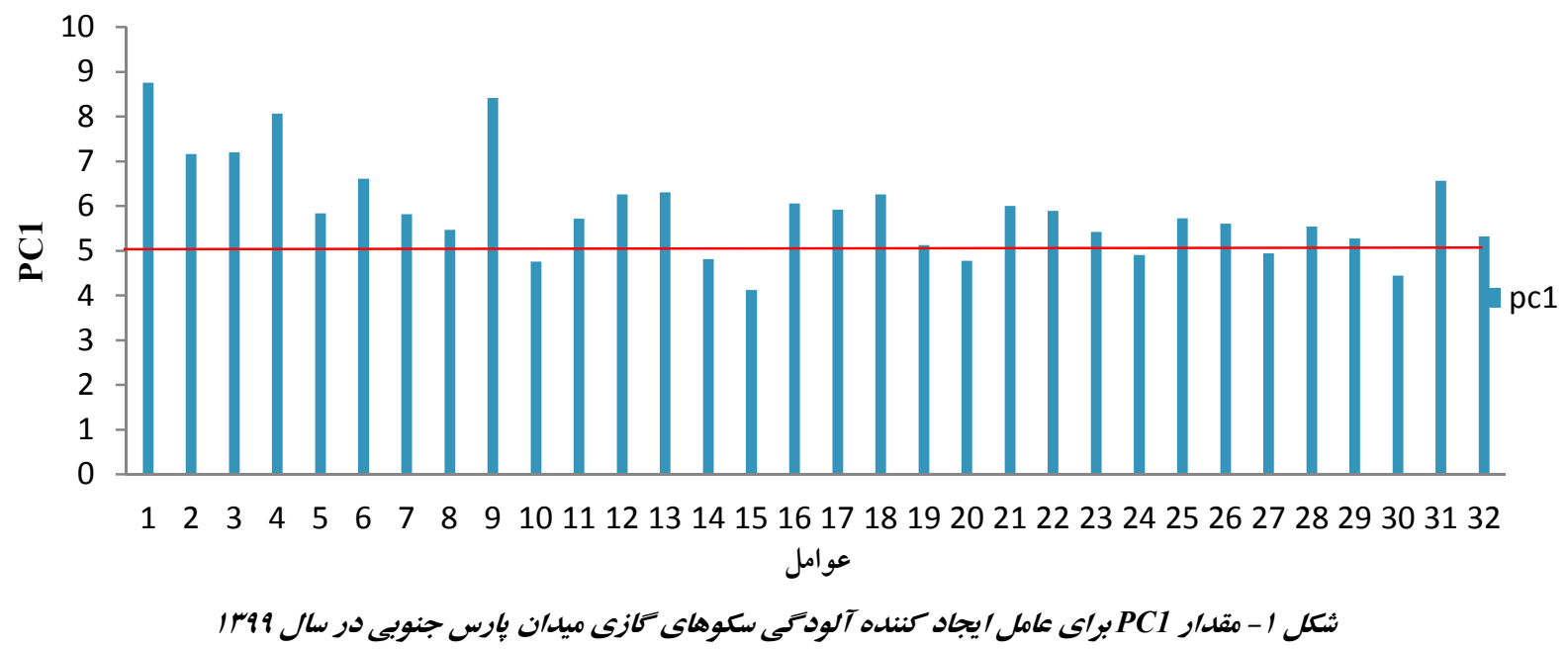

در دياكرام فعاليتهاى منجر شده به آلودگى هوا، گرههاى شرايط موجود عملياتى يكى از حالتها رخ مىدهد. هم-

فلرينَ و احتراق به عنوان ورودى به گره نهايى يا همان جنين گَرهاى احتراق زنراتورها، توليد برق و احتراق واتر

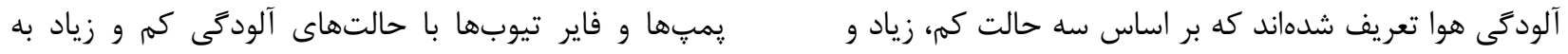
متوسط براى كرههاى ورودى شرايط گره آلودگى هوا در عنوان ورودى گره احتراق (Combustion) با حالتهاى وضعيتهاى كم، متوسط و زياد مشخص مىشود. گرههاى آلودىى كم، متوسط و زياد تعريف شدهاند. شكل r احتمال فلرينَ فشار بالا و پايين نيز با حالتهاى آلودَى كم و زياد آلودَى هوا توسط سكوهاى كَازى در سه سطح كم، متوسط

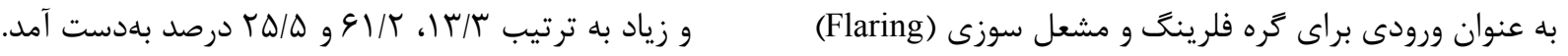
با حالتهاى كم، متوسط و زياد تعريف شدهاند و بسته به

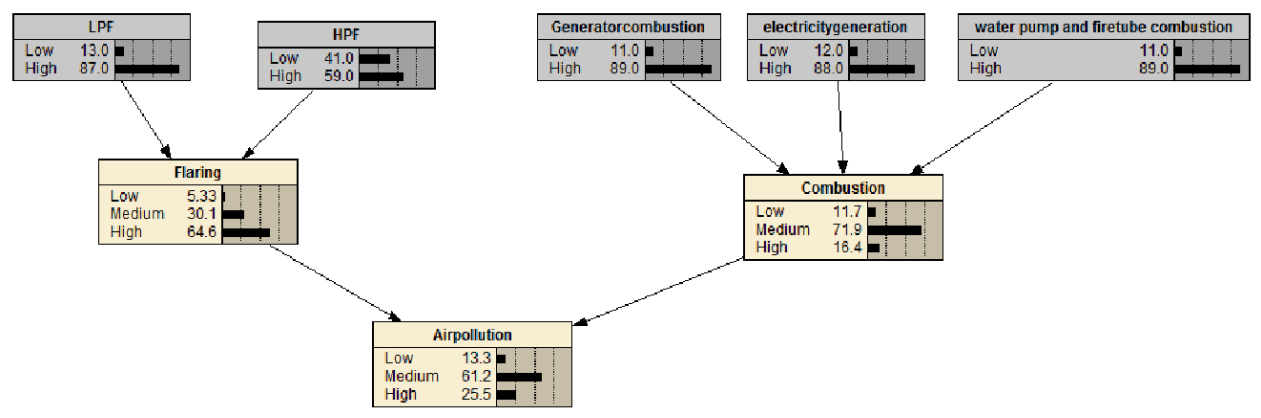

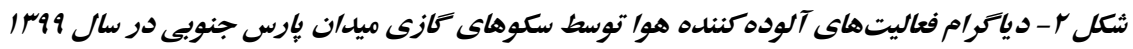




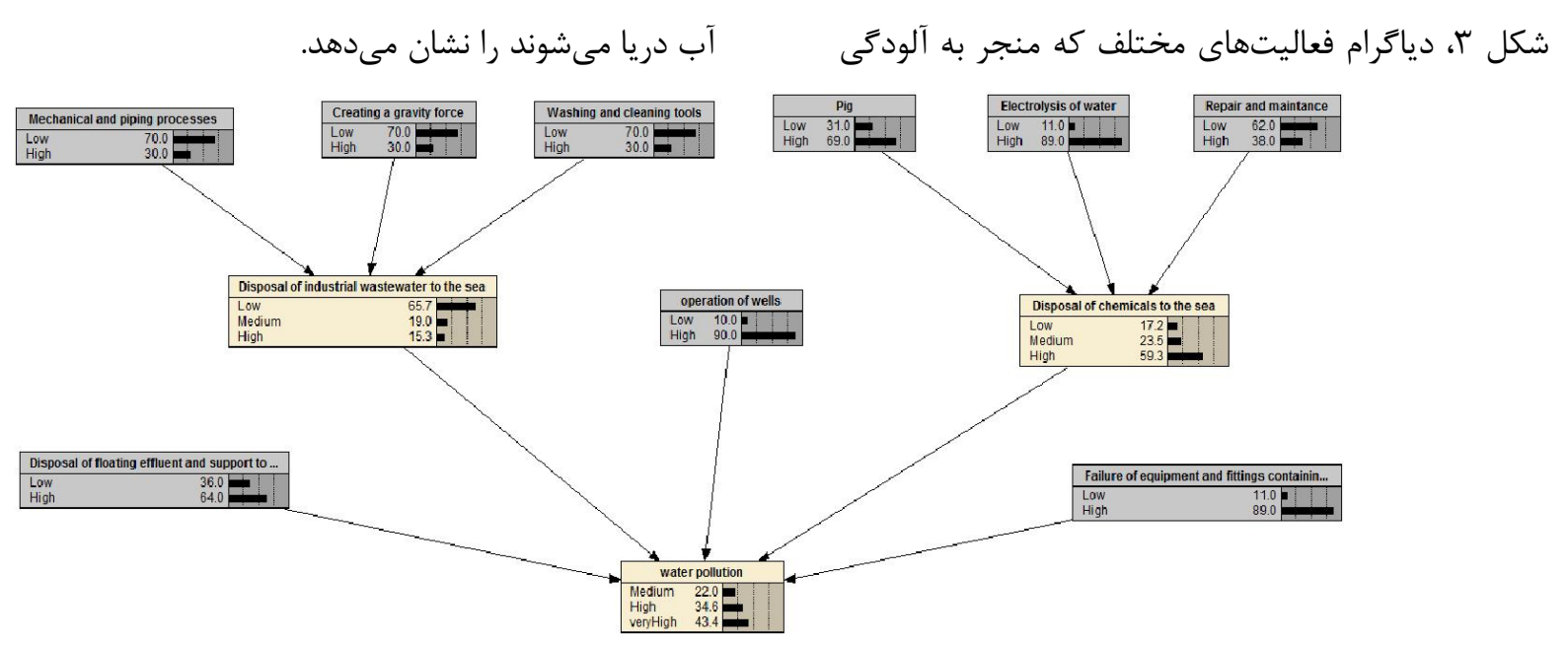

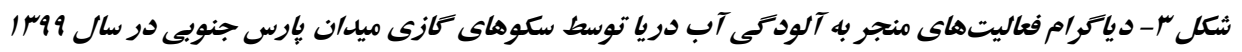

شيميايى به دريا، دفع يساب شناور به دريا، دفع يساب

صنعتى به دريا، بهره بردارى و فعاليت خاهها و خرابى

تجهيزات و اتصالات حاوى سيال تشكيل مىشود. اين خره داراى سه حالت متوسط، بالا و بسيار بالا مىباشد. احتمال آلودگى آب توسط سكوهاى گازى در سه سطح متوسط، زياد و خيلى زياد به ترتيب r T، شكل عا، دياكرام فعاليتهايى را نشان مى دهد كه منجر به آسيب به تنوع زيستى در محل حضور سكوهاى كازى مى
شستشوى تجهيزات، ايجاد نيروى گرانش و پِايِينگ و

فعاليتهاى مكانيكى در گره دفع يساب صنعتى به آب دريا دستهبندى شدهاند. بر اساس نظر كارشناسان سه حالت كم، متوسط و بالا براى اين گره مىتوان متصور شد. همرجنين فعاليتهاى يُيگرانى، الكتروليز آب و تعمير و نگذدارى منجر به دفع مواد شيميايى به آب دريا مىشوند و اين سه فعاليت در تره دفع مواد شيميايى به آب دريا دستهبندى شدهاند و بر اساس نظر كارشناسان سه حالت كم، متوسط و بالا براى اين گَره در نظر گَرفته شدهاند. گَره نهايى آلودَى آب كه در نهايت گره آلودگى سكو را ايجاد مى كند از گرههاى دفع مواد

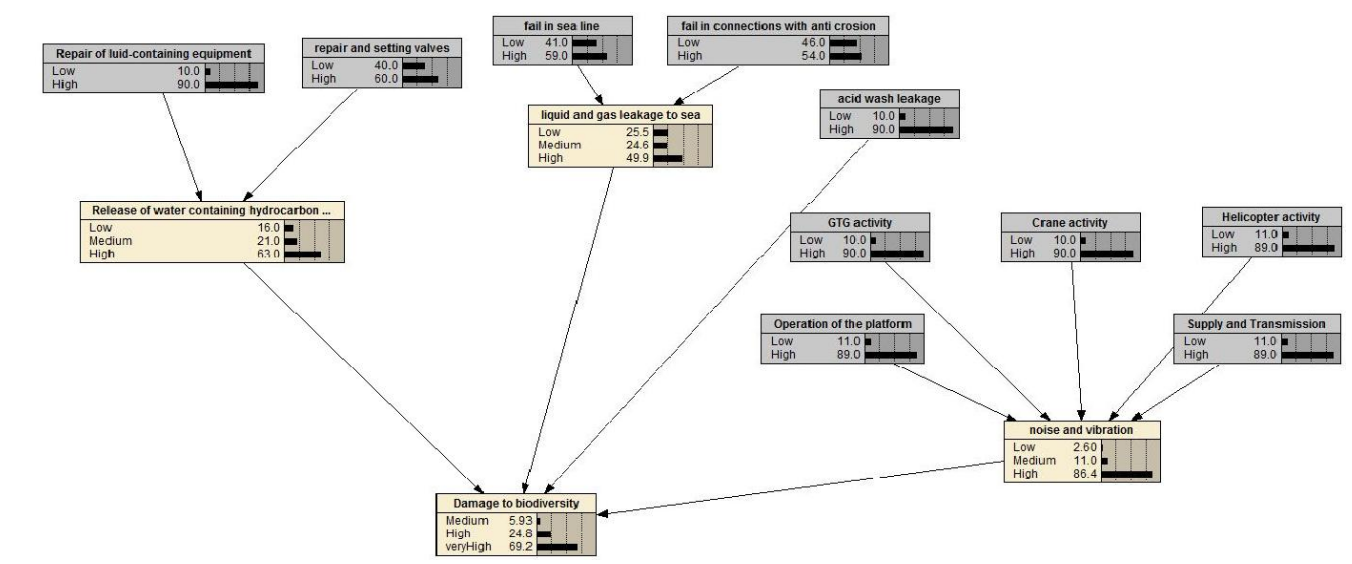

شكل ع- دياكرام فعاليتهاى منجر به آسيب به تنوع زيستى در آب دريا توسط سكوهاى كازى ميدان بإرس جنوبى در سال وبس| 
زيستى مىباشد. بر اساس نتايج شبكه بيزين براى آلودگى كلى سكو احتمال سطح متوسط ه9/ • درصد ، احتمال سطح بالا N/1 درصد، احتمال سطح بسيار بالا N/D درصد و احتمال سطح بحرانى VT/Q درصد محاسبه شده است.

\section{بحث}

سكوهاى دريايى به طور كلى به منظور اكتشاف و يا بهره بردارى از منابع نفت و گاز مورد استفاده قرار مى كيرند. در سالهاى اخير صنعت حفارى به سمت حفارى خاههاى نفت وكاز در آبهاى عميق روى آورده است. مواد نفتى از منابع مختلفى وارد آب مى به جاهها و دكلها و سكوهاى فراساحلى مىباشد. در خليج فارس تعداد بسيار زيادى سكوى نفتى و گازى وجود دارد كه به استخراج نفت و گاز براى بخش عظيمى از دنيا مى يردازند و آلودگىهاى محيط زيستى زيادى را به وجود آوردهاند [1/1]، لذا هدف از انجام اين يزوهش اين بود تا با استفاده از شبكههاى بيزين و تحليل مؤلفههاى اصلى، عواملى كه بيشترين يا بدترين اثر بر محيط را دارند را شناسايى و در

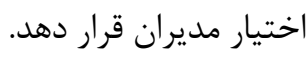

به اين منظور ابتدا دادهاى گردآورى شده از طريق مصاحبه با خبركان و كارشناسان ارائه شد. سيس با استفاده از آناليز اجزاى اصلى عواملى كه اثرات كمترى دارند حذف مىشوند و ساير عوامل در شبكههاى بيزين مورد بررسى قرار كرفت. اين دادهها از مطالعات قبلى همجون HAZOP و ارزيابى ريسكهاى جند سال (Hazard and Operability) اخير جهت استخراج عوامل و جنبههاى بارز استخراج شد. سيس از طريق : يرسشنامه، اخذ نظر از كارشناسان و
تعمير تجهيزات حاوى سيالات و تعمير و تنظيم ولوها منجر به تخليه هيدروكربنها به همراه آب در دريا مىشوند و به همين دليل اين دو فعاليت در شبكه بيزين به عنوان ورودى به گره تخليه هيدروكربنها در نظر گرفته شدهاند. خرابى در خط انتقال و اتصالات حاوى آنتى كروزن منجر به تخليه مايعات و مواد آنتىكروزن آلوده كننده به دريا مىشوند و منجر به آسيب به تنوع زيستى منطقه مي دو فعاليت در شبكه بيزين به عنوان ورودى به كره تخليه مايعات و مواد آنتى كروزن به دريا در نظر كرفته شدهاند. احتمالات شرطى اين گره بر اساس نظر كارشناسان براى سه حالت كم، متوسط و بالا تهيه شده است. فعاليت GTG (Gas Turbing Generator)، هليكويتر، جرثقيل، تأمين و انتقال، و عمليات روى سكو عمدتاً منجر به آلودگى صوتى، ارتعاش و نويز مىشوند كه در نهايت باعث آسيب به تنوع زيستى منطقه مى گردند. اين فعاليتها در شبكه بيزين به عنوان ورودى براى گره نويز و ارتعاش در نظر گرفته شدهاند. در شبكه بيزين اسيد واش، ارتعاش و نويز، تخليه آب و هيدروكربنها و مايعات و مواد آنتى كروزن به عنوان ورودى به گره آسيب به تنوع زيستى در نظر گرفته شدهاند. براى اين گره سه حالت متوسط، بالا و بسيار بالا در نظر گرفته شده است. احتمال آسيب به تنوعزيستى توسط سكوهاى كازى در سه سطح متوسط، بالا و بسيار بالا به ترتيب سوه/ه،

$$
\text { ( 99/T درصد بdدست آمد. }
$$

كره نهايى در شبكه بيزين كه آلودگى سكو مىباشد داراى جهار سطح متوسط، زياد، بسيار زياد و بحرانى است كه ناشى از سه دسته آلودگى هوا، آلودگى آب و آسيب به تنوع 
آلودگى هوا و انتشار كازهاى گلخانهاى ناشى از فعاليتهاى سكوى كازى مىتواند بر سلامتى خدمه سكو و كشتى اثر

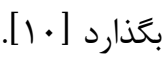

همرجنين اصلىترين عوامل ايجاد كننده آلودگى آب كه بر اساس شدت، مقدار و احتمال وقوعشان با استفاده از تحليل مؤلفههاى اساسى مشخص شدند شامل فعاليتهاى ياييينَ و فعاليتهاى مكانيكى ( and piping processes)، ايجاد نيروى گرانش، شستشو و تميزكارى ابزارآلات (Washing and cleaning tools)، دفع پِآب شناور Disposal of effluent support ship to ( يشتيبانى به دريا (the sea )، فعاليت جاهها (Operation of wells)، خرابى Failure of equipment ( تجهيزات و اتصالات حاوى سيال Piging (and fittings containing fluids processes و نكَدارى (Repair and maintance) بود. مدل بيزين آلودگى آب نشان داد كه احتمال سطح آلودگى متوسط براى اين دسته از آلودگىها بr درصد، احتمال سطح آلودگى بالا براى آلودگى آب ع/4 درصد و احتمال سطح آلودگى بسيار

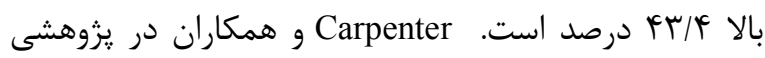
عنوان كردند نشت آلودگى از سكوها، عمليات نفتكشها، شست و شوى مخازن و تخليه آب مخزن تعادل، تصادف نفتكشها، تجهيزات پِالايشعاهى در سواحل و بسيارى عوامل ديخر همواره سلامت محيط زيست را تهديد مىكرده و مى كند [r]. Beyer و همكاران بيان كردند كه آب خروجى ناشى از فعاليت استخراج نفت و كاز فراساحلى توسط سكوهاى گازى بزرگترين منبع عملياتى آلودگى از صنعت نفت و كاز فراساحلى به دريا است [با II]
خبر Fان واحد ايمنى بهداشت و محيط زيست و بهره بردارى سكوهاى گازى و متخصصان محيط زيست، عواملى كه دراى اهميت بيشتر بودند مشخص و شناسايى شدند [9 19]. از بين اين عوامل، آنهايى كه در بين بيشتر كارشناسان مشترك بودند و اهميت بالاترى داشتند، انتخاب شدند. در نهايت بr عامل انتخاب و براى هر عامل نوع فرآيند، جنبه محيط زيستى و يِيامد محيط زيستى مشخص شد. در ادامه روند كار، آلودَى هاى ناشى از سكوى گَازى در سه دسته آلودگى هوا، آلودگى آب و آسيب به تنوع زيستى دسته بندى شدند. سيس دادههاى مرحله قبل را به نرم افزار Netica جهت تحليل شبكههاى بيزين وارد و سه دسته آلودگى ذكر شده

$$
\text { برسى كرديد. }
$$

بر اساس نتايج حاصل از اين يزوهش، فعاليتهاى احتراقى كه ناشى از حضور سكوى كازى در منطقه آبى بودند در دسته آلودگى هوا قرار گرفتند. اصلىترين عوامل ايجاد كننده آلودگى هوا كه بر اساس شدت، مقدار و احتمال وقوعشان با استفاده از تحليل مؤلفههاى اساسى مشخص شدند شامل فعاليتهاى فلرينگ و احتراق واتر پِمٍها و فاير تيوبها (Water pump and firetube combustion) زنراتورهاى تأمين برق (Power Generator)، فلرينگ فشار

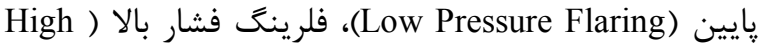
(Pressure Flaring آلودگى نشان دادكه سطح آلودگى كم داراى احتمال س/r درصد، سطح آلودگى متوسط داراى احتمال سطح آلودگى بالا دارى احتمال ه/ه د درصد بود. Elbisy در بررسى مديريت محيط زيستى يك سكوى گازى به همراه خطوطه لوله انتقال آن در درياى مديترانه بيان كردند كه 
919 بررسى آلودگى هاى محيط زيستى سكوهاى گازى دريايى ميدان پارس جنوبى ...

هاى كذشته و نبود بانك اطلاعاتى كافى در مورد تمامى ريامدهاى عوامل مختلف آلوده كننده در محل سكوهاى كازى دريايى اشاره نمود كه با بررسى جامع و استفاده از نظرات متخصصان از عدم اثر سوء اين محدوديتها بر نتايج ئزوهش اطمينان حاصل شد.

\section{نتيجه گَيرى}

تأثير فعاليت سكوهاى كازى در دو بخش آلودگى آب و تغيير در زيستگاه و تنوع گَونهاى زنده داراى بيشترين تأثير مىباشد كه از بين دو عامل با سطح آلودگى بسيار بالا، تأثير سكوهاى گازى بر تنوع زيستى و گونههاى زنده از بقيه موارد بارزتر است. همرجنين تركيب دو روش تحليل مؤلفههاى اصلى و شبكههاى بيزين جهت مديريت دادهها در زمينه مديريت محيط زيست سكو مثمر ثمر مىباشد. ييشنهاد مى عوامل ايجاد كننده آلودگى، راهحلهاى علمى و كارآمد بررسى گردد. به عنوان مثال توصيه مىشود به كمك طراحى يك سيستم خاص فشردهسازى گاز، ميزان فلرينَ يالايشَاهها بهطور جشمَيرى كاهش يابد و از اين طريق كازهايى كه تاكنون سوزانده مىشدند، جمعآورى گردند و

Fuel Gas سֶّ بهعنوان خوراك براى سيستمهايى همجِون

$$
\text { Turbines }
$$

اصلىترين عوامل ايجاد كننده آلودگى زيستى كه بر

اساس شدت، مقدار و احتمال وقوعشان با استفاده از تحليل مؤلفههاى اساسى مشخص شدند شامل فعاليتهاى تعمير Repair of liquidcontaining ( تجهيزات حاوى سيالات Repair and setting (equipment valves)، خرابى در خط لوله، خرابى تجهيزات و اتصلات Fail in connections with anti ) حاوى آنتى كروزن crosion جرثقيلها، فعاليت هليكويترها بر روى سكو، فعاليت و بهرهSupply and ) بردارى از سكو و تأمين و انتقال (Transmission احتمال سطح آلودگى متوسط براى اين دسته از آلودگىها r/Q/ه درصد مىباشد. احتمال سطح آلودگى بالا TF/A درصد و احتمال سطح آلودگى بسيار بالا و9/ ع درصد است. Punzo و همكاران در بررسى اثرات محيط زيستى فعاليتهاى سكوى كازى دريايى بر روى محيط اعماق دريا بيان كردند كه كميت، تفسير و تعميم اثرات محيط زيستى سكوهاى كازى دريايى دشوار است، زيرا اين اثرات محيط زيستى از طرق مختلف و غيرقابل ييشبينى و تحت تأثير متغيرهاى متعدد قرار دارند [r] [ب]. از محدوديتهاى موجود براى يزوهش حاضر مىتوان به عدم دسترسى آسان به كَزارشهاى HAZOP مربوط به سال 


\section{References}

[1] Sirat AP, Mehdipourpicha H, Zendehdel N, Mozafari H. Sizing and allocation of distributed energy resources for loss reduction using heuristic algorithms. In2020 IEEE power and energy conference at Illinois (PECI) 2020 Feb 27 (pp. 1-6). IEEE.

[2] Rosa L, D'Odorico P. The water-energy-food nexus of unconventional oil and gas extraction in the Vaca Muerta Play, Argentina. Journal of Cleaner Production 2019; 207: 743-50.

[3] Carpenter A. Oil pollution in the North Sea: the impact of governance measures on oil pollution over several decades. Hydrobiologia 2019; 845(1): 109-27.

[4] Gulas S, Downton M, D'Souza K, Hayden K, Walker TR. Declining Arctic Ocean oil and gas developments: Opportunities to improve governance and environmental pollution control. Marine Policy 2017; 75: 53-61.

[5] Sharifzadeh S, Ghodsi A, Clemmensen LH, Ersbøll BK. Sparse supervised principal component analysis (SSPCA) for dimension reduction and variable selection. Engineering Applications of Artificial Intelligence 2017; 65: 168-77.

[6] Papineau D. Thomas Bayes and the crisis in science. The Times Literary Supplement. 2018.

[7] Gustafsson FK, Danelljan M, Schon TB. Evaluating scalable bayesian deep learning methods for robust computer vision. InProceedings of the IEEE/CVF Conference on Computer Vision and Pattern Recognition Workshops 2020 (pp. 318-319).

[8] Kaikkonen L, Parviainen T, Rahikainen M, Uusitalo L, Lehikoinen A. Bayesian networks in environmental risk assessment: A review. Integrated Environmental Assessment and Management 2021; 17(1): 62-78.

[9] Sperotto A, Molina JL, Torresan S, Critto A, Pulido-Velazquez M, Marcomini A. A Bayesian Networks approach for the assessment of climate change impacts on nutrients loading. 
Environmental Science \& Policy 2019; 100: 21-

36.

[10]Elbisy MS. Environmental management of offshore gas platforms in Abu Qir Bay, Egypt. KSCE Journal of Civil Engineering 2016; 20(4): 1228-41.

[11]Ellis JI, Clark MR, Rouse HL, Lamarche G. Environmental management frameworks for offshore mining: the New Zealand approach. Marine Policy 2017; 84: 178-92.

[12]Beyer J, Goksøyr A, Hjermann DØ, Klungsøyr J. Environmental effects of offshore produced water discharges: A review focused on the Norwegian continental shelf. Marine environmental research 2020: 105155.

[13]Petropars. South Pars gas field. 2021; Available from: www.petropars.com [Farsi].

[14]Bucelli M, Paltrinieri N, Landucci G. Integrated risk assessment for oil and gas installations in sensitive areas. Ocean Engineering 2018; 150: 377-90.
[15]Government A. Environmental hazards at logarithmic scale 2020; Available from: https://www.industry.gov.au/.

[16]Parhizkar T, Rafieipour E, Parhizkar A. Evaluation and improvement of energy consumption prediction models using principal component analysis based feature reduction. Journal of Cleaner Production 2021; 279: 123866.

[17]Zhang C, Qin TX, Jiang B, Huang C. A comprehensive probabilistic analysis model of oil pipelines network based on Bayesian network. InIOP Conference Series: Earth and Environmental Science 2018 Feb 1 (Vol. 113, No. 1, p. 012083). IOP Publishing.

[18]Evtushenko N, Ivanov A, Evtushenko V. Oil pollution in the Persian Gulf: satellitemonitoring results in 2017. InConference of the Arabian Journal of Geosciences 2018 Nov 12 (pp. 343-347). Springer, Cham.

[19]Deeva I, Bubnova A, Andriushchenko P, Voskresenskiy A, Bukhanov N, Nikitin NO, Kalyuzhnaya AV. Oil and Gas Reservoirs 
Parameters Analysis Using Mixed Learning of

Bayesian Networks. InInternational Conference

on Computational Science 2021 Jun 16 (pp.

394-407). Springer, Cham.

Punzo E, Gomiero A, Tassetti AN, Strafella P, Santelli A, Salvalaggio V, Spagnolo A,
Scarcella G, De Biasi AM, Kozinkova L, Fabi

G. Environmental impact of offshore gas activities on the benthic environment: a case study. Environmental Management 2017; 60(2): $340-56$. 


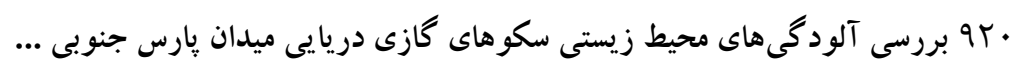

\title{
Investigation of Environmental Pollution of Offshore Gas Platforms in South Pars Field with Principal Component Analysis and Bayesian Network Model from 2019 to 2020: A Descriptive Study
}

\author{
R. Mohammad Zadeh', M. Mirza Ebrahim Tehrani ${ }^{\top}$, S. A. Jozi ${ }^{r}$, R. Moogouei ${ }^{{ }^{\natural}}$ \\ Received: 07/03/21 Sent for Revision: 18/05/21 Received Revised Manuscript: 21/08/21 Accepted: 22/08/21
}

Background and Objectives: Globally, rising energy demand has driven humans to extract oil and gas, even in the depth of seas. This is also important in the Persian Gulf and has caused a lot of environmental pollution. The purpose of this study was to determine the environmental pollution of offshore gas platforms by Principal Component Analysis methods and Bayesian network model.

Materials and Methods: This descriptive study was conducted from 2019 to 2020 on offshore gas platforms in South Pars field. The required data were collected through interviews with experts. Then, using the analysis of the main components, the factors with less effect were eliminated and other factors in Bayesian networks were investigated.

Results: Based on the results of Bayesian network, for the overall pollution of the platform, the probability of the average level was $0.95 \%$, the probability of the high level was $8.11 \%$, the probability of the very high level was $18.5 \%$, and the probability of the critical level was $72.5 \%$. The results of the Principal Component Analysis section showed that the highest variance is related to the first Principal Component and its value is approximately $40 \%$, and also the highest eigenvalue is related to this component with the value of 1.909 .

Conclusion: The effect of gas platform activity in the two parts of water pollution and biodiversity damage has the greatest effect. Among the two factors with very high levels of pollution, the effect of gas platform on biodiversity and living species is more pronounced than the others. Also, the combination of two methods of Principal Component Analysis and Bayesian networks for data management in the field of platform environmental management is fruitful.

Key words: Pollution, Gas platform, Principal Component, Bayesian network

Funding: This study did not have any funds.

Conflict of interest: None declared.

How to cite this article: Mohammad Zadeh R, Mirza Ebrahim Tehrani M, Jozi SA, Moogouei R. Investigation of Environmental Pollution of Offshore Gas Platforms in South Pars Field with Principal Component Analysis and Bayesian Network Model from 2019 to 2020: A Descriptive Study. J Rafsanjan Univ Med Sci 2021; 20 (8): 905-20. [Farsi]

\footnotetext{
1- PhD Candidate, Dept. of Environment, Faculty of Marine Sciences and Technology, North Tehran Branch, Islamic Azad University, Tehran, Iran, ORCID: 0000-0002-7807-4857

2- Assistant Prof., Dept. of Environment, Faculty of Marine Sciences and Technology, North Tehran Branch, Islamic Azad University, Tehran, Iran, ORCID: 0000-0002-3752-3361.

(Corresponding Author): Tel: (021) 88080778, Fax: (021) 88080778, E-mail: HSE1400@gmail.com

3- Prof., Dept. of Environment, Faculty of Marine Sciences and Technology, North Tehran Branch, Islamic Azad University, Tehran, Iran, ORCID: 0000-0002-4486-1297

4 Associate Prof., Dept. of Planning, Environmental Management and Education, North Tehran Branch, Islamic Azad University, Tehran, Iran, ORCID: 0000-0001-6613-0818
}

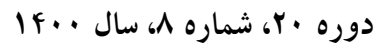

مجله دانشخاه علوم يزشكى رفسنجان 